\title{
"Balancing state budget expenditures: A case of Ukraine using the simplex method"
}

\begin{tabular}{|c|c|}
\hline AUTHORS & $\begin{array}{l}\text { Inna Shkolnyk (iD } \\
\text { R } \\
\text { Yuriy Ladyka (D) } \\
\text { Volodymyr Orlov (D) } \\
\text { Khaled Aldiwani } \\
\text { Yevhenii Kozmenko (D) }\end{array}$ \\
\hline ARTICLE INFO & $\begin{array}{l}\text { Inna Shkolnyk, Yuriy Ladyka, Volodymyr Orlov, Khaled Aldiwani and Yevhenii } \\
\text { Kozmenko (2021). Balancing state budget expenditures: A case of Ukraine using } \\
\text { the simplex method. Public and Municipal Finance, 10(1), 34-46. } \\
\text { doi:10.21511/pmf.10(1).2021.04 }\end{array}$ \\
\hline DOI & http://dx.doi.org/10.21511/pmf.10(1).2021.04 \\
\hline RELEASED ON & Friday, 02 July 2021 \\
\hline RECEIVED ON & Sunday, 11 April 2021 \\
\hline ACCEPTED ON & Monday, 28 June 2021 \\
\hline LICENSE & $\begin{array}{l}(c)) E Y \\
\text { This work is licensed under a Creative Commons Attribution } 4.0 \text { International } \\
\text { License }\end{array}$ \\
\hline JOURNAL & "Public and Municipal Finance" \\
\hline ISSN PRINT & $2222-1867$ \\
\hline ISSN ONLINE & $2222-1875$ \\
\hline PUBLISHER & LLC "Consulting Publishing Company "Business Perspectives" \\
\hline FOUNDER & LLC "Consulting Publishing Company "Business Perspectives" \\
\hline
\end{tabular}

NUMBER OF REFERENCES

21

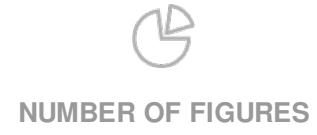

5
NUMBER OF TABLES

5

(C) The author(s) 2022. This publication is an open access article. 


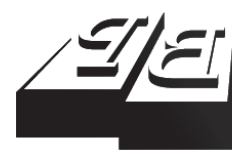

\section{BUSINESS PERSPECTIVES}

O

LLC "CPC "Business Perspectives" Hryhorii Skovoroda lane, 10, Sumy, 40022, Ukraine www.businessperspectives.org
Received on: $11^{\text {th }}$ of April, 2021 Accepted on: $28^{\text {th }}$ of June, 2021 Published on: $2^{\text {nd }}$ of July, 2021

(C) Inna Shkolnyk, Yuriy Ladyka, Volodymyr Orlov, Khaled Aldiwani, Yevhenii Kozmenko, 2021

Inna Shkolnyk, Dr., Professor, Professor of the Department of Finance, Banking and Insurance, Sumy State University, Ukraine. (Corresponding author)

Yuriy Ladyka, Ph.D. (Law), Senior Lecturer of the Department of Private and Social Law Sumy National Agrarian University, Ukraine.

Volodymyr Orlov, Ph.D. (Economics), First Deputy Head of the Dnipropetrovsk Regional State Administration, Ukraine.

Khaled Aldiwani, Ph.D. student, University of Customs and Finance, Dnipro, Ukraine; Higher Institute of Science and Technology, Libya.

Yevhenii Kozmenko, Ph.D. Student, Sumy State University, Ukraine.
Inna Shkolnyk (Ukraine), Yuriy Ladyka (Ukraine), Volodymyr Orlov (Ukraine), Khaled Aldiwani (Ukraine, Libya), Yevhenii Kozmenko (Ukraine)

\section{BALANCING STATE BUDGET EXPENDITURES: A CASE OF UKRAINE USING THE SIMPLEX METHOD}

\begin{abstract}
The consolidated state budget expenditures reflect the condition of performance by a country of its basic functions and allow defining priority directions for the implementation of state policy. Their optimal ratio allows satisfying the interests of citizens, business and society as a whole, and can provide a significant impetus for economic growth. The analysis of state budget expenditures using the example of Ukraine showed that their structure is unbalanced. Therefore, the purpose of the study was to find the necessary balance. The optimization of Ukraine's state budget expenditures was carried out using the simplex method based on their structure from 2007 to 2019. Since the priorities of Ukraine's strategic economic and political development are the implementation of the EU standards and norms, the structure of the EU's state budget expenditures is chosen as a guideline for determining the optimal structure of expenditures. As a result, it is determined that in order to harmonize the structure of the Ukrainian budget expenditures with the approaches implemented in the European Union, minimal changes in public order spending are required. In addition, significant areas of funding include healthcare, economic activity, social protection and security. At the same time, intergovernmental transfers need to be significantly reduced, the amount of which should be revised after the completion of the financial decentralization reform.
\end{abstract}

\section{Keywords}

public finance, national functions, index of structural changes, economic and mathematical modeling

JEL Classification

H50, H60, H61, H72

\section{INTRODUCTION}

When forming the state budget expenditures, the main tasks are taken into account, which are determined by state policy in all areas of its implementation. Support for economic and social development, ensuring the state's defense capabilities, protecting the interests of citizens and businesses, and creating safe living conditions, both in terms of public order and environmental safety, depend on their optimality and balance. Effectively generated state budget expenditures can become a trigger for economic growth, which, in turn, will increase the revenue side of the state budget. Thus, the qualitative formation of state budget expenditures according to their functional content becomes the basis for developing a country's balanced development strategy.

The analysis of expenditures structure of Ukraine's state budget showed its heterogeneity. Expenditures such as national functions, public order, safety and judiciary, social protection and social security, and inter-budgetary transfers have been a priority for the state over the past ten years. At the same time, important expenditure items such as environmental protection, housing and communal services, 
healthcare, defense and economic development account for a much smaller share. Given this heterogeneity of the expenditures of Ukraine's state budget, structural optimization is needed: an increase in budget support in some areas and a reduction in others.

\section{LITERATURE REVIEW}

With regard to the expenditure side, it should be generated depending on the developed strategic objectives of the Government. In this case, the use of state budget funds will be the most effective.

As for research on this issue, the analysis of the Scopus scientometric database has shown its growing importance. The original search query "budget expenditures" provided information, in which the first publication dated back to 1910 and was published by Harvard University researcher Porritt (1910), but it concerned mostly political issues, and only partially addressed the problems related to the formation of the UK budget, in particular, in terms of the formation of certain types of taxes. Analysis of scientific publications for the period from 1920 to 1975 showed that the vast majority of scientific publications were either not available upon request, or were isolated cases and dealt with budgeting problems at the micro level.

One of the first works found in this database, Burger (1975), is devoted to the main directions of structural budgetary policy development in the Netherlands, its analysis since the 60s of the twentieth century. The paper determines the normative size of the structural budget deficit, the consequences of non-compliance with certain norms of expenditures at the national level.

In the same year, Tramontana (1975) examined the effects of budget deficits and surpluses in the short and long term, and determined that the impact of these indicators was more important in the long run. The main conditions for a neutral fiscal policy, the pressure that public debt may exert on the formation of the revenue side in the future and, therefore, on the implementation of fiscal policy in the country, as well as the formation of prices for government bonds, were studied. It is also emphasized that, depending on the structure of the budget expenditures, there may be significant changes in the ratio between savings and investments.
The growing relevance of research in this area is also evidenced by studies conducted by Mawejje and Odhiambo (2020), who analyzed the theoretical basis for studying the problems of forming the optimal ratio of state budget revenues and expenditures. In particular, the paper analyzes classical theories: Keynesian theory, Ricardo equivalence theory, neoclassical theory, and the hypothesis of the political budget cycle. Based on the analysis of these theories, the authors identified the basic determinants for generating state budget deficit as a consequence of the predominance of budget expenditures over revenues. In particular, they include economic growth rates, the current level of public debt, unemployment, GDP per capita, inflation, defense spending, and the level of urbanization in the country. And no less important is the quality of budgetary institutions and the political situation in the country. Parui (2020) conducted a study on the impact of public spending and its balance on aggregate demand and economic growth in the country, based on the post-Keynesian model. The study failed to obtain an unambiguous answer to the existence of dependencies, in particular, it was found that if demand is determined by wages, the growth of public investments may reduce aggregate demand, but if aggregate demand is formed based on aggregate income, then the growth of public investment leads to the stimulation of demand.

The problem of generating state budget expenditures is actively studied in Islamic finance. For the Middle East countries, it is important not only to form a budget, but also to find opportunities to optimize revenue and expenditure components, since public finances in these countries significantly depend on the market of energy, especially oil. Budget revenues directly depend on fluctuations in oil prices on the world market. Therefore, the question often arises of revising the structure of expenditures as a result of changes in the revenue side. In particular, this problem is studied by Eid (2020) on the example of the state of Qatar. Melé et al. (2020) evaluate the causal links between revenues and expenditures of the state budget of 
Malaysia using Granger causality tests. It is noted that the use of the policy of increasing tax pressure does not restrain budget deficit.

Budget formong is extremely relevant for Ukrainian scientists. Vasyutynska (2019) investigates the issue of improving the efficiency of budget expenditure management. In her opinion, the main tools for improving the efficiency of state budget expenditure management are the conclusion of contracts with heads of budget institutions, which must include performance indicators, determination of material remuneration for obtaining savings in public procurements, etc.

Cherkashyna (2017) investigated the optimization of the structure of public spending in the formation of neoliberal model and found that the structure of public spending in Ukraine is not optimal. The author also identified the main causes of imbalance, namely, the expenditure side does not stimulate economic growth, low efficiency of public debt management, excessive fiscalization and bureaucratization of the budget process, low level of control over budget expenditures.

Romenska et al. (2020) identify the problems of implementing budget planning for the development of a predictable and balanced budget together with the priorities of the state. They note that this will increase predictability and transparency, stabilize the budget in the medium term, solve problems of efficient and high-quality use of budget funds for economic and social recovery.

Komarynska et al. (2019) explore ways to reduce the tax burden on the state budget and optimize budget expenditures on public services, the maintenance of budget-funded institutions, etc.

Abad et al. (2020) investigate the problem of the stabilizing role of balancing budget rules in the conditions of uneven formation of budget expenditures using a dynamic model. They note the existence of cyclical budget spending that can stabilize, both locally and globally, endogenous business cycle fluctuations in the face of uncertainty.

For Ukraine, the issue of inter-budgetary transfers is extremely relevant and significantly affects the formation of the expenditure side, especial- ly in the context of administrative and territorial reform, accompanied by the process of financial decentralization and the growing role of local budgets. Lysiak et al. (2020), studying the financial sustainability of local budgets in Ukraine, substantiate the need for its systematic assessment, as well as budget adjustments, improving the quality of budget planning, including the interaction between local budgets and the state budget.

Examining the golden rule of public finance in current monetary policy, Shvets (2020) found a positive impact of effective public spending on long-term economic growth.

Shkolnyk et al. (2020) argue that the formation of state budget expenditures affects the economic security of a country. Using Ukraine and Poland as an example, the authors prove the existence of a significant impact on the state of public finance, including state budget expenditures, on the level of financial security. At the same time, this influence is decisive for Ukraine, and much less for Poland. Bulatova et al. (2020), studying the impact of global financial transformations on the formation of economic security in Central and Eastern Europe, note that the most significant determinants are high volatility of stock market capitalization and public finance indicators - uneven distribution of public funds, growing external debt. The authors note that the indicators of global and regional state funds and indicators of the state of financial markets have different vectors.

Chornovol et al. (2020) note that a key deterrent in the formation of a high-quality public financial management system is the uncertainty of economic processes, which leads to fluctuations in macroeconomic indicators. Here, the state budget deficit, generated as a result of the mismatch between the revenue and expenditure parts of the state budget and an increase in the share of public debt, poses a significant threat to financial and economic stability. It is the public debt and the state budget deficit that have a significantly greater negative impact than the pro-cyclical nature of fiscal policy pursued in Ukraine. Chugunov and Nasibova (2021) noted that the state of formation of state budget expenditures affects the level of socio-economic development. Based on the analysis of panel data from 17 Eurozone countries, they investigated the 
impact of state budget spending on social protection on the level of socio-economic development of countries. As a result, a discrepancy was found between the amount of funding for social protection spending and social contributions.

Based on a structural analysis of the revenue and expenditure side of the state budget, Frolov et al. (2021) built a forecast of gaps between revenues and expenditures. They found that the income gap is much larger than the cost gap. This indicates a low level of budget planning in Ukraine.

Thus, summarizing the above, the purpose of this paper is to redistribute state budget expenditures by functional classification using the simplex method and to ensure the optimal level of structural changes in Ukraine's GDP.

\section{DATA AND METHODOLOGY}

In general, the classical optimization problem, which belongs to the group of structural economic and mathematical models, is to find the optimal (maximum or minimum) value of the objective function $\mathrm{F}\left(\mathrm{x}_{1}, \mathrm{x}_{2}, \ldots, \mathrm{x}_{n}\right)$ subject to compliance with the system of established constraints gi $\left(\mathrm{x}_{1}, \mathrm{x}_{2}, \ldots\right.$, $\left.\mathrm{x}_{n}\right)\{\leq=\geq\} b_{i}$. Mathematically, this can be presented as the following objective function:

$$
F=\sum_{j=1}^{n} c_{j} x_{j} \rightarrow \max (\min ),
$$

with the following constraints:

$$
\begin{aligned}
& \sum_{j=1}^{n} a_{i j} x_{j} \leq b_{i}(i=1, \ldots k), \\
& \sum_{j=1}^{n} a_{i j} x_{j}=b_{i}(i=k+1, \ldots l), \\
& \sum_{j=1}^{n} a_{i j} x_{j} \geq b_{i}(i=l+1, \ldots m), \\
& x_{j} \geq 0,
\end{aligned}
$$

where $a_{i j}, b_{i}$, and $c_{i j}$ are constant values.

To optimize the items of public expenditures, it is necessary to regulate the corridor of permissible alterations for each public expenditure item separately. In the context of the chosen vector of Ukraine's European integration, the main guideline in determining the limits of the optimal amount of public expenditure is the practice of distributing government spending in the $\mathrm{EU}$ for the period 2010-2018, obtained through the information base of the Organization for Economic Cooperation and Development. Since statistical information on government spending in the EU is presented in the form of panel data, Stata 13.0 software is used for their analysis, which allows processing this category of data.

The purpose of this model is to redistribute budgetary financial resources between structural items of the budget so that it provides the optimal level of structural changes in GDP. In this case, the share of each item of budget expenditures in GDP

\begin{tabular}{|c|c|}
\hline $\begin{array}{l}\text { Indicator } \\
\text { symbols }\end{array}$ & Indicator \\
\hline Y & $\begin{array}{c}\text { Integral coefficient of structural changes in GDP by } \\
\text { type of activity }\end{array}$ \\
\hline \multicolumn{2}{|r|}{ Share in GDP of budget expenditures on } \\
\hline 1 & National functions \\
\hline$x_{2}$ & Defense \\
\hline$x_{3}$ & Public order, security and the judiciary \\
\hline$x_{4}$ & Economic activity \\
\hline$x_{5}$ & Environmental protection \\
\hline$x_{6}$ & Housing and utilities infrastructure \\
\hline$x_{7}$ & Health care \\
\hline$x_{8}$ & Spiritual and physical development \\
\hline$x_{9}$ & Education \\
\hline$x_{10}$ & Social protection and social security \\
\hline$x_{11}$ & Inter-budgetary transfers \\
\hline
\end{tabular}
will be unknown (Table 1).

Table 1. Symbols of indicators used to build economic and mathematical optimization model in terms of government spending

To determine the objective function, it is necessary to formalize the functional relationship between the integrated coefficient of structural changes in GDP by type of activity and public expenditure items. Multiple regression analysis is a good tool for identifying the nature and strength of the relationship between variables.

A linear multifactor regression model has been built, which makes it possible to detect changes in the average level of the effective trait depending on changes in the factorial feature of the next type performing the role of the objective function in the study:

$F_{z}=Y=\alpha+\beta_{1} x_{1}+\beta_{2} x_{2}+\ldots .+\beta x+\varepsilon$, 
where $i$ - the total number of research indicators; $\alpha-$ free term of the regression equation; $\beta_{i}$ - coefficients of the regression equation; $X_{i}$ - independent variables of the study; and $\varepsilon$ - standard error of the study.

In this case, the coefficients of the regression equation are constants $c$. Thus, the final form of the objective function for building an optimization model for the state budget expenditure items has been obtained:

$F_{\dot{c}} \bar{\sigma} \alpha+c_{1} x_{1}+c_{2} x_{2}+\ldots+c x+\varepsilon \rightarrow \max$.

As a dependent variable, the integrated coefficient of structural changes in GDP by type of activity is used, and as independent variables - eleven items of government expenditures.

\section{RESULTS}

The results of regression analysis are presented in Table 2.

Given the determined parameters of the regression model, the objective function has the following form:

$$
\begin{aligned}
& F_{c}=0.297 x_{1}-0.502 x_{2}-0.444 x_{3}+ \\
& +0.096 x_{4}+0.027 x_{5}+0.463 x_{6}+0.142 x_{7}- \\
& -0.209 x_{8}-1.085 x_{9}+0.082 x_{10}- \\
& -0.056 x_{11} \rightarrow \max .
\end{aligned}
$$

\begin{tabular}{|c|c|c|c|c|c|c|c|}
\hline Variable & $\begin{array}{c}\text { Regression equation } \\
\text { parameters }\end{array}$ & $R^{2}$ & $\mathbf{R}$ & $F^{*}$ & $t^{* *}$ & $p$-value & Type of relationship \\
\hline$x_{0}$ & 0.821 & \multirow{12}{*}{0.74} & \multirow{12}{*}{0.85} & \multirow{12}{*}{7.00} & 4.600 & 0.000 & - \\
\hline$x_{1}$ & 0.297 & & & & 1.332 & 0.194 & $\uparrow$ Direct \\
\hline$x_{2}$ & -0.502 & & & & -1.743 & 0.093 & $\downarrow$ Converse \\
\hline$x_{3}$ & -0.444 & & & & -1.550 & 0.133 & $\downarrow$ Converse \\
\hline$x_{4}$ & 0.096 & & & & 0.291 & 0.773 & $\uparrow$ Direct \\
\hline$x_{5}$ & 0.027 & & & & 0.150 & 0.882 & $\uparrow$ Direct \\
\hline$x_{6}$ & 0.463 & & & & 2.968 & 0.006 & $\uparrow$ Direct \\
\hline$x_{7}$ & 0.142 & & & & 0.533 & 0.598 & 个 Direct \\
\hline$x_{8}$ & -0.209 & & & & -1.426 & 0.165 & $\downarrow$ Converse \\
\hline$x_{9}$ & -1.085 & & & & -4.687 & 0.000 & $\downarrow$ Converse \\
\hline$x_{10}$ & 0.082 & & & & 0.562 & 0.578 & 个 Direct \\
\hline$x_{11}$ & -0.056 & & & & -0.394 & 0.697 & $\downarrow$ Converse \\
\hline
\end{tabular}

Table 2. Regression analysis results to identify the relationship between government spending and the integrated coefficient of structural changes in GDP by type of activity

Source: Authors' calculations.

Note: $*$ - the value of Fisher's F-test should exceed the table value (in this case, where $\alpha=0.05$, it is 2.165 at a level of $p$ 0.00002 ). ${ }^{* *}$ - the value of Student's $t$-test should exceed the table value (in this case, where $\alpha=0.05$, it is 1.7). 
In addition, expenditures on defense, public order, education, security and the judiciary determine the rate of structural shifts in GDP towards reduction. The corresponding regression coefficients are $0.502,0.444$, and 1.085 , respectively.

After evaluating the main quality criteria of the built regression model (coefficient of determination, Fisher's and Student's tests), one can draw the following conclusions about the adequacy of the obtained modeling results:

- the value of $\mathrm{t}$-statistics for some independent variables is greater than its table value (1.7) at a given level of significance, while $p$-level is less than 0.05 , which indicates statistical significance of influence of the corresponding regressors on the dependent variable;

- the calculated value of Fisher's test of 7.00 is greater than the corresponding table value (2.165) at a given level of significance, while $p$-level is less than 0.05 , which confirms the statistical significance of the entire regression equation;

- the coefficient of determination $R^{2}$ is 0.74 , which indicates that the change in the integrated coefficient of structural changes in GDP according to types of activity by $74 \%$ is due to changes in government spending.

The obtained results of the built regression model can be evaluated as adequate and those that correctly describe the reality, while the regression coefficients can be used as parameters of the objective function to solve the optimization problem.

Despite the high living standards of most EU member states, one cannot yet speak of their economic homogeneity. In terms of public welfare, there is a significant gap between some countries, the nature and structure of which can be analyzed in detail with descriptive statistics, including, in particular, arithmetic mean, median, mode, minimum and maximum value, standard deviation, asymmetry and excess.

To get an overall picture of the level of variation in government spending in the EU by item over the period 2010-2018, a boxplot will be drawn (Figure 1).

Government spending items such as defense, environment and social protection, health care and inter-budgetary transfers have the widest range between the lower and upper "whiskers" on the boxplot. In addition, points outside the eleventh plot indicate the presence of outliers that do not fit into the interquartile ratio between the data in this series.



Figure 1. Boxplot of the value of government spending by item for the EU countries in 2010-2018 


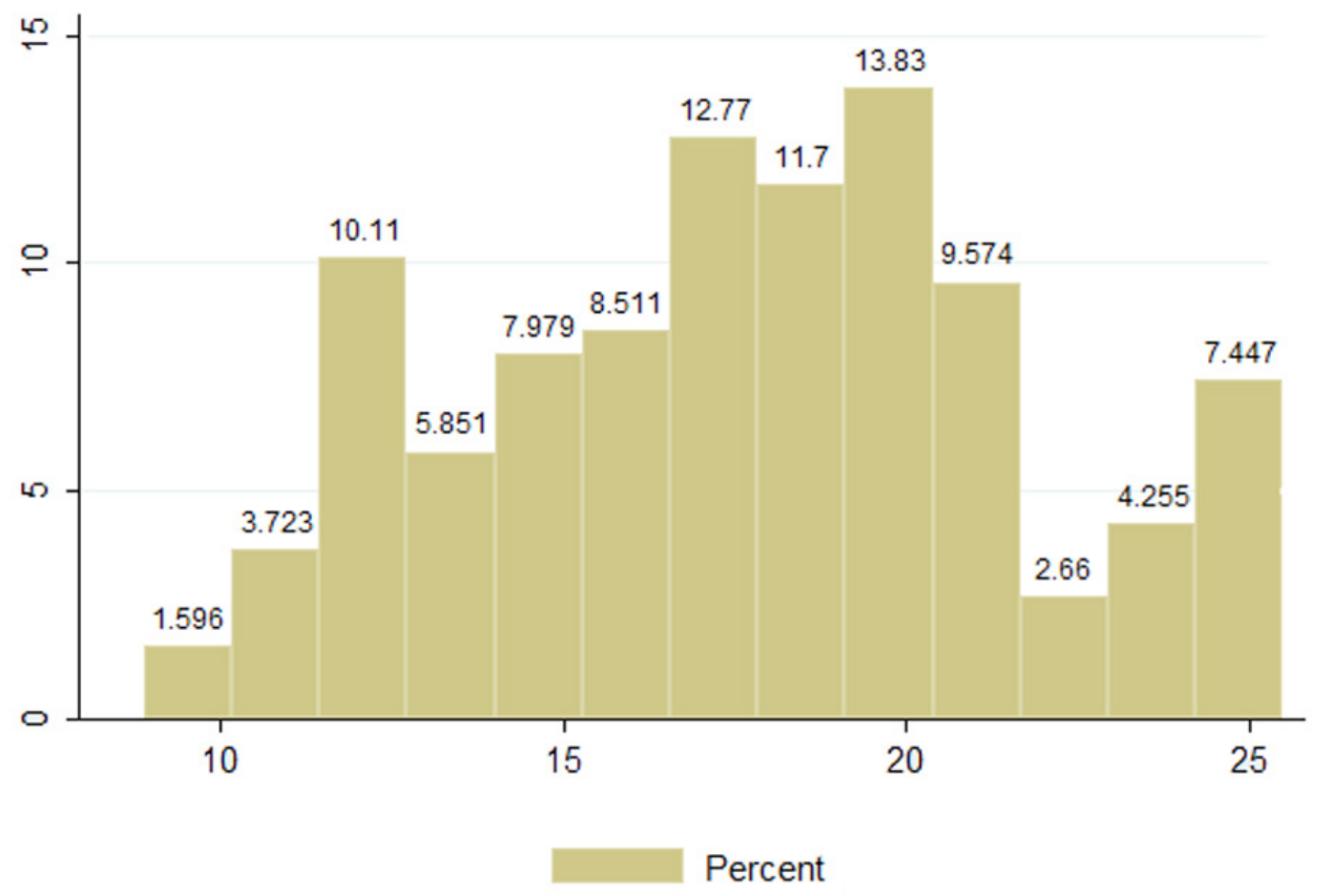

Figure 2. Distribution of EU countries by public spending on social security in 2010-2018

Sorting the data according to the growth of the relevant boxplots, a visualization of the EU countries' position is obtained, for example, by the level of government spending aimed at ensuring social security (Figure 2). For example, the share of public expenditures in the structure of GDP for most EU countries is quite high and ranges from $17 \%$ to $21 \%$, since about $50 \%$ of the studied values are in this range. Denmark has the maximum value of expenditures (more than $25 \%$ ), and Ireland has the minimum value (less than $5 \%$ ).

To analyze the nature of the distribution for each item of government spending, a histogram was built with a bell-shaped line on it, which corresponds to the normal (Gaussian) distribution law. The closest to the normal distribution is the distribution of spending on national security, defense and education (Figure 3). Prerequisites for the distribution of some data to conform to the normal law include:

- equality of mode values (the value that is most often observed in the sample) and median values (the value that is in the center of the series and divides it in half);
- standard deviation (square root of variance of the series) equals one;

- asymmetry (shifting of the graph top to the left or right depending on the sign of the value) and excess (measures of peakedness of the graph) equal zero.

An important condition is the use of arithmetic mean and median to analyze the mean value of the series. If the series is normally distributed, the arithmetic mean is used, otherwise, the median is used.

A more detailed picture of the analysis of public expenditure by item in the EU can be obtained using basic descriptive statistics (Table 3).

After analyzing the descriptive statistics, it is necessary to refute the assumption of a normal distribution law for several items of government spending, since none of the above conditions are met: the values of mode and median are not equivalent, standard deviation is not equal to one, asymmetry and excess are other than zero, which indicates the asymmetry of all indicators. Therefore, median should be used to characterize the average level of government spending in the EU. 
Source: Authors' calculations.

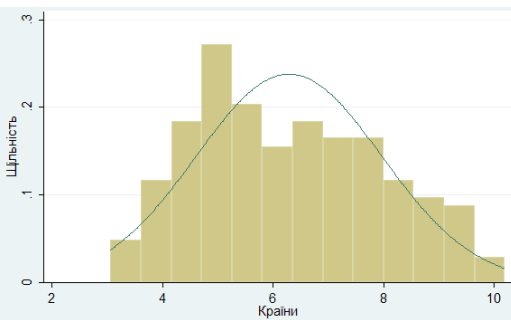

$x 1$

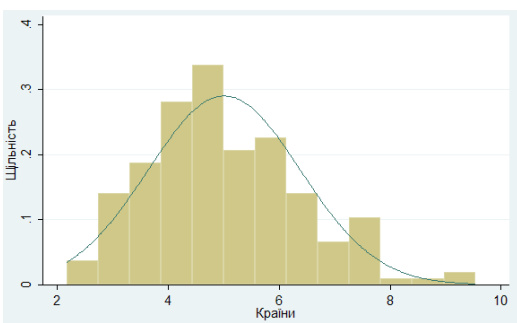

$x 4$

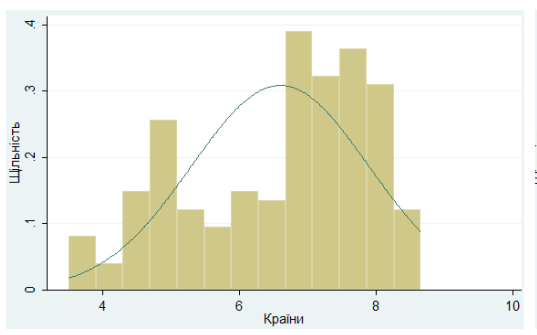

$x 7$

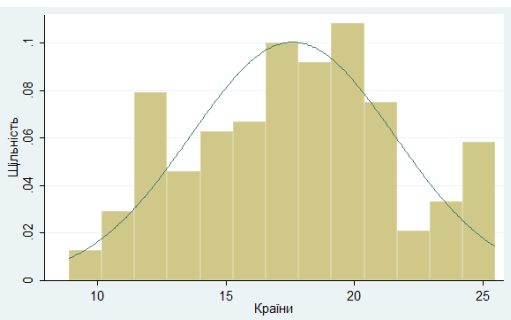

$x 10$

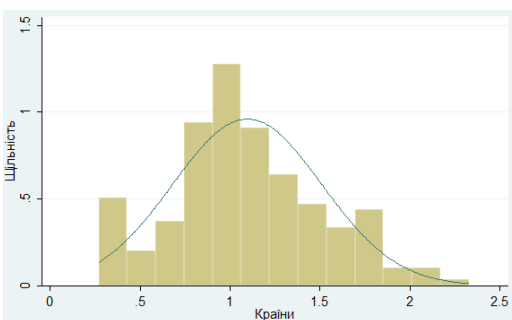

$x 2$

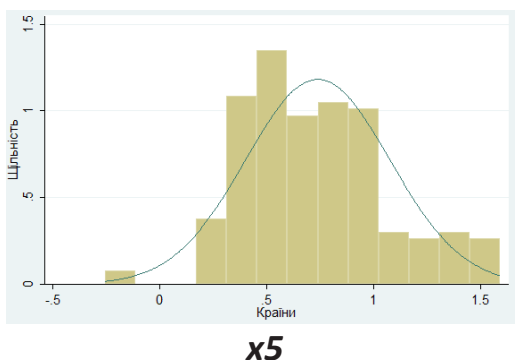

$x 5$

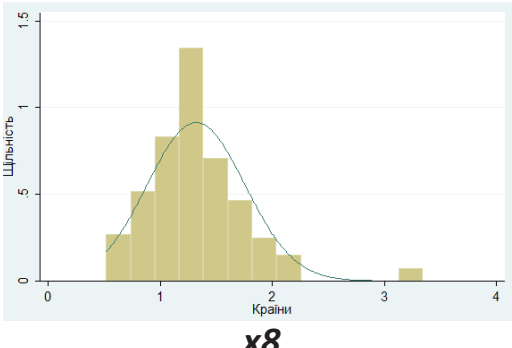

$x 8$

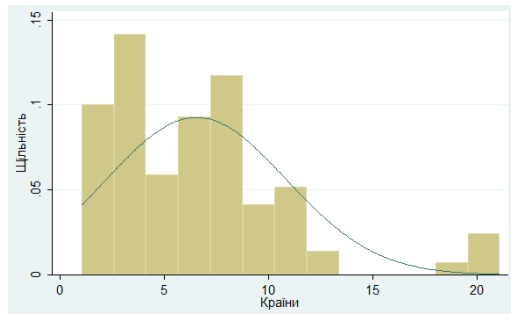

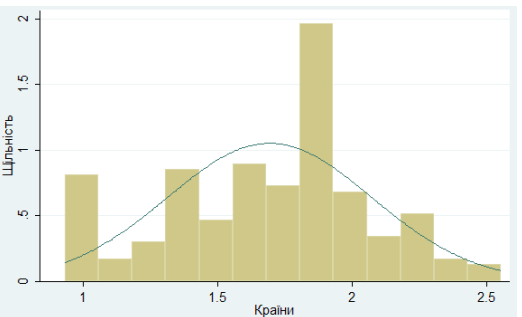

x3

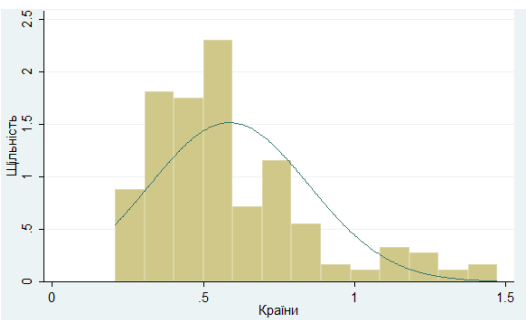

$x 6$

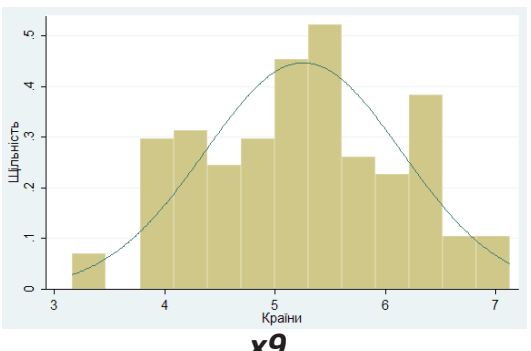

Figure 3. Density of distribution of public expenditures in the EU by item in 2010-2018 (the y-axis shows the density, the $\mathrm{x}$-axis shows the options)

Table 3. Descriptive statistics of government spending in the EU, 2010-2018

Source: Authors' calculations.

\begin{tabular}{|c|c|c|c|c|c|c|c|c|}
\hline \multirow[b]{2}{*}{ Type of government spending } & \multicolumn{8}{|c|}{ Descriptive statistics } \\
\hline & $\begin{array}{c}\text { Arithmetic } \\
\text { mean }\end{array}$ & Median & Mode & Min & Max & $\begin{array}{l}\text { Standard } \\
\text { deviation }\end{array}$ & Asymmetry & Excess \\
\hline National functions & 6.29 & 6.14 & - & 3.06 & 10.2 & 1.68 & 0.26 & 2.14 \\
\hline Defense & 1.09 & 1.05 & - & 0.27 & 2.33 & 0.41 & 0.26 & 2.83 \\
\hline $\begin{array}{l}\text { Public order, security and the } \\
\text { judiciary }\end{array}$ & 1.69 & 1.75 & - & 0.93 & 2.55 & 0.38 & -0.21 & 2.4 \\
\hline Economic activity & 5.0 & 4.78 & - & 2.17 & 9.53 & 1.37 & 0.59 & 3.29 \\
\hline Environmental protection & 0.74 & 0.69 & - & 0.26 & 1.59 & 0.34 & 0.41 & 3.17 \\
\hline Housing and utilities infrastructure & 0.59 & 0.52 & - & 0.21 & 1.47 & 0.26 & 1.21 & 4.2 \\
\hline Health care & 6.6 & 6.93 & - & 3.51 & 8.65 & 1.29 & -0.56 & 2.21 \\
\hline Spiritual and physical development & 1.32 & 1.26 & - & 0.52 & 3.34 & 0.44 & 1.41 & 7.52 \\
\hline Education & 5.25 & 5.26 & - & 3.16 & 7.14 & 0.89 & -0.003 & 2.28 \\
\hline $\begin{array}{l}\text { Social protection and social } \\
\text { security }\end{array}$ & 17.59 & 17.79 & - & 8.9 & 25.48 & 3.97 & 0.02 & 2.25 \\
\hline Inter-budgetary transfers & 6.52 & 6.57 & - & 1.04 & 21.09 & 4.3 & 1.46 & 5.72 \\
\hline
\end{tabular}


Table 4. Descriptive statistics of government spending in Ukraine, 2010-2019

Source: Authors' calculations.

\begin{tabular}{|c|c|c|c|c|c|c|c|c|}
\hline \multirow{2}{*}{$\begin{array}{l}\text { Type of government } \\
\text { spending }\end{array}$} & \multicolumn{8}{|c|}{ Descriptive statistics } \\
\hline & $\begin{array}{l}\text { Arithmetic } \\
\text { mean }\end{array}$ & Median & Mode & Min & Max & $\begin{array}{l}\text { Standard } \\
\text { deviation }\end{array}$ & Asymmetry & Excess \\
\hline National functions & 4.11 & 3.92 & - & 2.35 & 6.89 & 1.06 & 0.68 & 0.05 \\
\hline Defense & 1.86 & 1.91 & - & 0.88 & 3.68 & 0.86 & 0.38 & -1.18 \\
\hline $\begin{array}{l}\text { Public order, security and the } \\
\text { judiciary }\end{array}$ & 2.85 & 2.62 & - & 2.15 & 4.16 & 0.49 & 0.93 & 0.05 \\
\hline Economic activity & 2.31 & 2.31 & - & 0.77 & 4.69 & 0.98 & 0.44 & -0.20 \\
\hline Environmental protection & 0.20 & 0.17 & - & 0.08 & 0.48 & 0.10 & 0.88 & -0.01 \\
\hline $\begin{array}{l}\text { Housing and utilities } \\
\text { infrastructure }\end{array}$ & 0.01 & 0.00 & - & 0.00 & 0.20 & 0.04 & 4.30 & 21.04 \\
\hline Health care & 0.70 & 0.61 & - & 0.28 & 1.36 & 0.30 & 0.51 & -0.79 \\
\hline $\begin{array}{l}\text { Spiritual and physical } \\
\text { development }\end{array}$ & 0.31 & 0.26 & - & 0.16 & 0.60 & 0.13 & 0.66 & -0.85 \\
\hline Education & 1.80 & 1.67 & - & 0.93 & 2.97 & 0.53 & 0.46 & -0.49 \\
\hline $\begin{array}{l}\text { Social protection and social } \\
\text { security }\end{array}$ & 5.49 & 5.49 & - & 3.65 & 11.18 & 1.35 & 1.84 & 7.07 \\
\hline Inter-budgetary transfers & 8.17 & 7.90 & - & 5.13 & 12.83 & 1.68 & 0.77 & 0.84 \\
\hline
\end{tabular}

Given mode and median values that are not equiv- The share of the vast majority of government alent, standard deviation other than one, and spending in the structure of GDP in EU countries asymmetry and excess that are not zero, the medi- is higher than in Ukraine. There are three excepan is also used to analyze the average level of pub- tions: spending on defense, public order, security lic spending in Ukraine (Table 4). and the judiciary, and inter-budgetary transfers. The state's significant attention to the level of secu-

The average level of government spending as a share of GDP by item for EU countries is shown in Figure 4. rity in the country is explained by the unstable geopolitical situation in the east of the country and in the Autonomous Republic of Crimea.

Source: Authors' calculations.

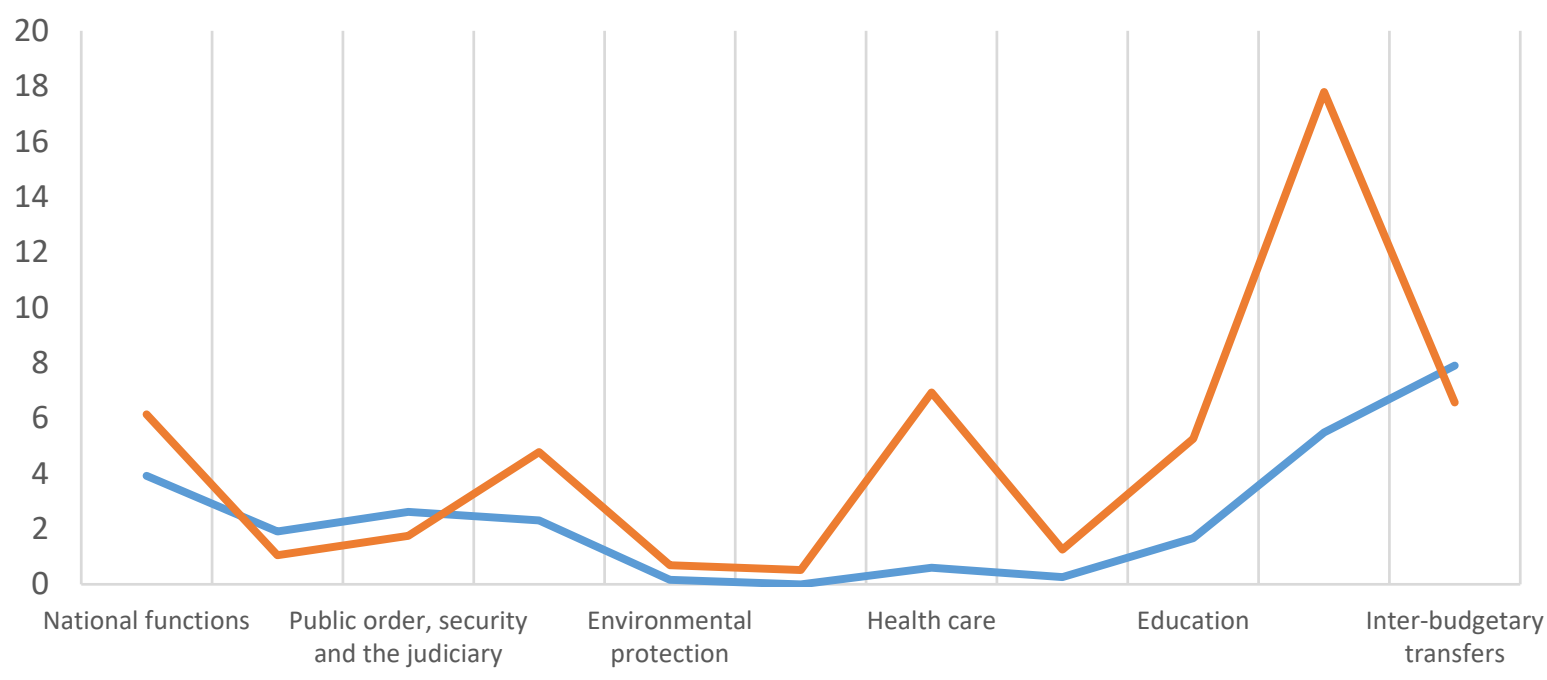

Average level of public expenditures in Ukraine,\% of GDP

Average level of public expenditures in EU countries,\% of GDP

Figure 4. Average level of government spending as a share of GDP for the EU and Ukraine, 2010-2018 
Given the statistical analysis, when building the optimization model, the following constraints were used:

$$
\begin{aligned}
& 3.063 \leq x_{1} \leq 10.196, \\
& 3.2 \leq x_{2}, \\
& 2.553 \leq x_{3} \leq 5, \\
& 2.168 \leq x_{4} \leq 9.535, \\
& 0.256 \leq x_{5} \leq 1.592, \\
& 0.209 \leq x_{6} \leq 1.473, \\
& 3.513 \leq x_{7} \leq 8.654, \\
& 0.518 \leq x_{8} \leq 3.344,
\end{aligned}
$$

$$
\begin{aligned}
& 3.166 \leq x_{9} \leq 7.132, \\
& 8.903 \leq x_{10} \leq 25.481, \\
& 1.036 \leq x_{11} \leq 21.094,
\end{aligned}
$$

When determining the limits, exceptions include national expenditures on defense and public order, security and the judiciary. In particular, given the geopolitical instability in Ukraine, the amount of regulated minimum government spending on defense should be at least 3\% of GDP. Although there are no such requirements for public order, security and judicial spending, this sector also needs additional funding of $2.5-5 \%$.

Another important aspect when formulating the constraints on the optimization model is the lim-

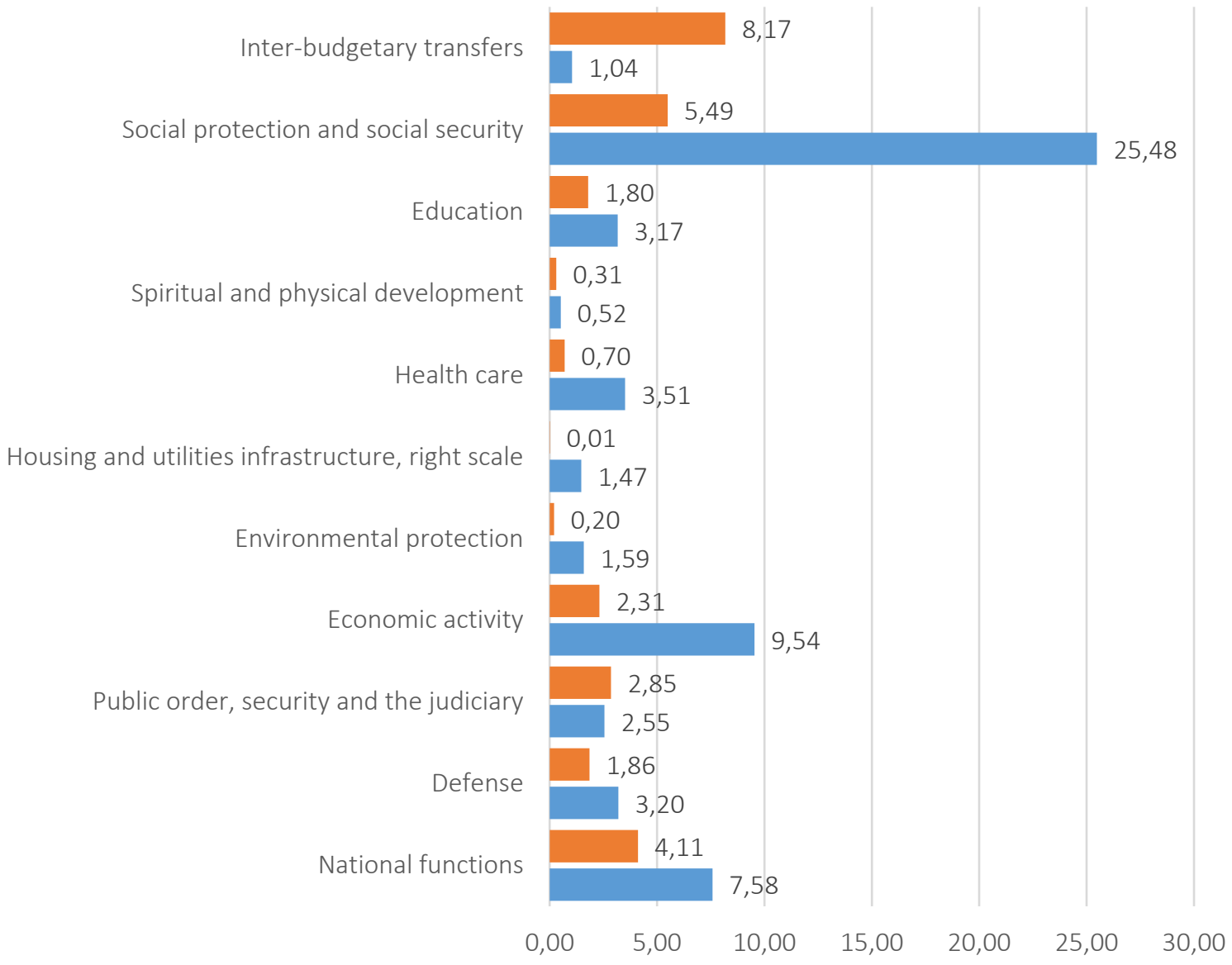

- Average level of expenditures,\% of GDP Optimal value of expenditures, $\%$ of GDP

Figure 5. Comparison of the obtained optimal and available average levels of distributing state budget expenditures as a share of GDP, \% 
Table 5. Direction and rates of changes in national expenditures, \% of GDP

Source: Authors' calculations.

\begin{tabular}{|c|c|c|c|c|}
\hline Item & $\begin{array}{c}\text { Average value for } \\
2010-2020\end{array}$ & Optimal value & Growth rate & $\begin{array}{c}\text { Direction of } \\
\text { change }\end{array}$ \\
\hline National functions & 4.11 & 7.58 & 1.84 & $\uparrow$ \\
\hline Defense & 1.86 & 3.20 & 1.72 & $\uparrow$ \\
\hline Public order, security and the judiciary & 2.85 & 2.55 & 0.89 & $\leftrightarrow$ \\
\hline Economic activity & 2.31 & 9.54 & 4.12 & $\uparrow$ \\
\hline Environmental protection & 0.20 & 1.59 & 7.87 & $\uparrow$ \\
\hline Housing and utilities infrastructure & 0.01 & 1.47 & 102.39 & $\uparrow$ \\
\hline Health care & 0.70 & 3.51 & 5.05 & $\uparrow$ \\
\hline Spiritual and physical development & 0.31 & 0.52 & 1.67 & $\uparrow$ \\
\hline Education & 1.80 & 3.17 & 1.76 & $\uparrow$ \\
\hline Social protection and social security & 5.49 & 25.48 & 4.64 & $\uparrow$ \\
\hline Inter-budgetary transfers & 8.17 & 1.04 & 0.13 & $\downarrow$ \\
\hline
\end{tabular}

its of the objective function, since it must be maximized to a certain limit. According to the method used to calculate the integrated coefficient of structural changes in GDP by type of activity $(Y)$, this value cannot be negative.

The fluctuating nature of the coefficient during 2010-2019 indicates the structural instability of Ukraine's GDP, which is largely due to the relationship with economic activities, which are seasonal in nature (agriculture), and unstable geopolitical situation in the country as a whole. Under these conditions, the maximum value of the objective function is the average level of the coefficient of structural changes of 0.2 presented as follows:

$$
0 \leq F_{c} \leq 0.2
$$

As a result of calculations using the available integrated coefficient of structural changes in Ukraine's GDP by type of activity, the optimal distribution of Ukraine's state budget expenditures is presented in Figure 5. It is necessary to compare the determined optimal value of national expenditures with the existing average level (Figure 5). As can be seen, some items need to be reduced, and some should be increased.

An item of expenditures aimed at ensuring public order, security and the judiciary requires minimal changes in the amount of public funding. The optimal value of this item differs from the real average value by only $0,3 \%$. Items of national expenditures related to national func- tions, defense, education, spiritual and physical development need more attention in adjusting the amount of funding. In accordance with the built optimization model, all these areas of public funding need to be nearly doubled.

Items such as economic activity, environmental protection, housing and utilities infrastructure, health care, social protection and social security require significant additional state funding at the level of 4.1 times for economic activity and up to 102 times for housing and utilities sector. It should be noted that, unlike other items of government spending, inter-budgetary transfers require a significant reduction - by 7.8 times. The direction and rate of change in national expenditures by item are presented in Table 5 .

Having identified the practice of national funding of the European Union as a benchmark, the optimal level of funding for the public sector corresponds to the level of Sweden; the needs of the defense sector exceed the maximum level in the EU (Estonia - 2.3\%); public order, security and the judiciary - Slovakia; economic activity, housing and utilities sector, health care - Latvia; environmental protection - the Netherlands; spiritual and physical development, education and inter-budgetary transfers - Ireland; and social protection and social security - Finland.

Therefore, in order to achieve the goals of sustainable development and improve Ukraine's position in the European community, a significant reorientation of public spending is required. 


\section{CONCLUSION}

Analysis of state budget expenditures using the example of Ukraine showed that their structure is unbalanced, and therefore the purpose of the study was to optimize their relationship.

Multiple regression analysis showed that an increase in the share of GDP in government spending on public functions, economic activity, environmental protection, housing and communal services, health, social protection and social security will make the GDP structure less stable, which may lead to an imbalance in the country's economic stability.

At the same time, special attention should be paid to expenditures aimed at ensuring national functions and housing and communal services, since the coefficients for these items are the highest among those that directly affect the integrated coefficient of structural changes in GDP by type of activity -0.297 and 0.463 , respectively.

As a result of modeling the optimal structure of state budget expenditures, it was found that items such as economic activity, environmental protection, housing and communal services, health care, social protection and social security require significant additional funding from the state at a level of 4.1 times for economic activity and up to 102 times for housing and communal services. It should be noted that one of the budget items, inter-budgetary transfers, in contrast to other items, needs a significant reduction - by 7.8 times. This result is fully consistent with the real need to change the structure of expenditures and will ensure economic growth, reduce political and economic dependence of Ukraine on external factors and create the basic conditions for achieving sustainable development goals.

\section{AUTHOR CONTRIBUTIONS}

Conceptualization: Inna Shkolnyk.

Data curation: Yuriy Ladyka.

Formal analysis: Inna Shkolnyk, Volodymyr Orlov, Khaled Aldiwani.

Investigation: Yuriy Ladyka, Khaled Aldiwani, Yevhenii Kozmenko.

Methodology: Inna Shkolnyk, Volodymyr Orlov.

Supervision: Inna Shkolnyk.

Validation: Khaled Aldiwani, Yevhenii Kozmenko.

Visualization: Yuriy Ladyka, Volodymyr Orlov, Yevhenii Kozmenko.

Writing - original draft: Volodymyr Orlov, Khaled Aldiwani.

Writing - review \& editing: Inna Shkolnyk, Yuriy Ladyka, Yevhenii Kozmenko.

\section{REFERENCES}

1. Abad, N., Lloyd-Braga, T., \& Modesto, L. (2020). The failure of stabilization policy: Balancedbudget fiscal rules in the presence of incompressible public expenditures. Journal of Economic

Dynamics and Control, 120, 103996. http://doi.org/10.1016/j. jedc.2020.103996

2. Bulatova, O., Marena, T., Chentukov, Y., \& Shabelnyk, T. (2020). The impact of global financial transformations on the economic security of Central and Eastern European countries. Public and Municipal Finance, 9(1), 1-13. http://dx.doi.org/10.21511/ pmf.09(1).2020.01

3. Burger, H. (1975). Structural budget policy in the Netherlands. De Economist, 123(3), 329-351. http://doi.org/10.1007/ BF02115742

4. Cherkashyna, T. S. (2017). Problems of the optimization of the government expenditure structure in the Ukrainian conditions of formation the neo-liberal model of economic development. Hlobalni ta natsionalni problemy ekonomiky - Global and national problems of economics, 15, 143-147. (In Ukrainian). Retrieved from http://global-national.in.ua/archive/15-2017/27.pdf

5. Chornovol, A., Tabenska, J., Tomniuk, T., \& Prostebi, L. (2020). Public finance 
management system in modern conditions. Investment Management and Financial Innovations, 17(4), 402-410. http://doi.org/10.21511/ imfi.17(4).2020.34

6. Chugunov, I., \& Nasibova, O. (2021). Public funding of social protection: Impact on social indicators in Eurozone countries. Investment Management and Financial Innovations, 18(2), 181-192. http://doi.org/10.21511/ imfi.18(2).2021.15

7. Eid, A. G. (2020). The impact of government expenditure on GDP in the state of Qatar: A nonlinear ARDL approach. International Journal of Sustainable Economy, 12(1), 25-43. http://doi. org/10.1504/IJSE.2020.107859

8. Frolov, S., Bogacki, S., Shukairi, F., \& Bukhtiarova, A. (2021) Evaluation of state budget structural changes based on the coefficient method. Investment Management and Financial Innovations, 18(1), 55-64. http://dx.doi.org/10.21511/ imfi.18(1).2021.05

9. Komarynska, Yu., Kryshevych, O., Linnyk, N., Karelin, V., \& Kofanova, O. (2019). Publicprivate partnership as an effective mechanism for attracting private investment in achieving the aims the socio-economic development of Ukraine. Problems and Perspectives in Management, 17(4), 469-479. http://dx.doi. org/10.21511/ppm.17(4).2019.38

10. Lysiak, L., Kachula, S., Hrabchuk, O., Filipova, M., \& Kushnir, A. (2020). Assessment of financial sustainability of the local budgets: case of Ukraine. Public and Municipal Finance, 9(1), 4859. http://dx.doi.org/10.21511/ pmf.09(1).2020.05

11. Mawejje, J., \& Odhiambo, N. M. (2020). The determinants of fiscal deficits: A survey of literature. International Review of Economics, 67(3), 403-417. http:// doi.org/10.1007/s12232-02000348-8

12. Melé, M., Quarto, A., \& Abbafati, C. (2020). On the fiscal policy in Malaysia: An econometrical analysis between the revenue-and expenditure. Research in World Economy, 11(1), 1-10. http://doi. org/10.5430/rwe.v11n1p1

13. Parui, P. (2020). Government expenditure and economic growth: A post-Keynesian analysis. International Review of Applied Economics, 35(3-4), 597-625. http://doi.org/10.1080/02692171.2 020.1837744

14. Porritt, E. (1910). The struggle over the Lloyd-George budget. Quarterly Journal of Economics, 24(2), 243-278. http:// doi.org/10.2307/1883558

15. Romenska, K., Chentsov, V., Rozhko, O., \& Uspalenko, V. (2020). Budget planning with the development of the budget process in Ukraine. Problems and Perspectives in Management, 18(2), 246-260. http://dx.doi. org/10.21511/ppm.18(2).2020.21

16. Shkolnyk, I., \& Bukhtiarova, A. (2020). Analysis of the consolidated budget of Ukraine based on harrington's desirability function. International scientific journal "Internauka". Series: "Economic sciences", 9(41). (In Ukrainian). https://doi. org/10.25313/2520-2294-2020-96281

17. Shkolnyk, I., Kozmenko, O., Nowacki, R., \& Mershchii, B. (2020). Dependence of the state of public finances on their transparency and the level of corruption in a country. Economics and Sociology, 13(4), 281-296. http://doi.org/10.14254/2071789X.2020/13-4/18

18. Shkolnyk, I., Kozmenko, S., Polach, J., \& Wolanin, E. (2020). State financial security: Comprehensive analysis of its impact factors. Journal of International Studies, 13(2), 291 309. http://doi.org/10.14254/2071$8330.2020 / 13-2 / 20$

19. Shvets, S. (2020). The golden rule of public finance under active monetary stance: endogenous setting for a developing economy. Investment Management and Financial Innovations, 17(2),
216-230. http://dx.doi. org/10.21511/imfi.17(2).2020.17

20. Tramontana, A. (1975). Budget policy, capital formation and steady growth. De Economist, 123(3), 397-415. http:// doi.org/10.1007/BF02115746

21. Vasyutinska, L., \& Zvieriakov, M. (Ed.). (2019). Improving of budget expenditures management effectiveness: problems and pragmatics. Visnyk sotsialnoekonomichnykh doslidzen, 1(69), 140-148. Odessa: Odessa National Economic University. (In Ukrainian). Retrieved from http://vsed.oneu.edu.ua/collections/2019/69/pdf/1-69-2019.pdf 